\title{
WSPÓŁCZESNE POLSKIE NAZWY ULIC MOTYWOWANE TOPONIMAMI PRZEJŚCIOWYMI
}

Słow tematyczne: nazwy ulic, plateonimy, nazwy przejściowe, Ziemie Odzyskane, Komisja Ustalania Nazw Miejscowości

\section{WSTĘP}

Przedmiotem refleksji badawczej są polskie plateonimy (nazwy ulic) pochodzące od tzw. nazw przejściowych (inaczej: przedkomisyjnych), nadawanych przez osadników zasiedlanym miejscowościom na tzw. Ziemiach Odzyskanych ${ }^{1}$ w pierwszych latach powojennych, zwykle zanim nastąpiły oficjalne decyzje nazewnicze KUNM (Komisji Ustalania Nazw Miejscowości przy Ministerstwie Administracji Publicznej). Zostaną one omówione bardziej szczegółowo w dalszej części artykułu.

Wiele plateonimów motywowanych jest nazwami miast czy wsi. Przykładem mogą być: aleja Krakowska (: miasto Kraków) w Warszawie czy ul. Załęska (: wieś Załęże) w Rzeszowie (obydwie nazwy kierunkowe), ul. Słocińska w Rzeszowie (nazwa lokalizująca - upamiętnia włączoną w obręb Rzeszowa dawną wieś Słocina, której główną ulicą była obecna Słocińska), ul. Zwierzyniecka w Rzeszowie (nazwa przeniesiona z Krakowa), ul. Biskupińska w Poznaniu (nazwa pamiątkowa, która metonimicznie upamiętnia fakt, że przy tej ulicy mieszkał prof. Józef Kostrzewski, prowadzący wykopaliska w Biskupinie) czy ul. Belgradzka w Gdańsku (nazwa konwencjonalna, część gniazda nazewniczego nawiązującego do miast Europy). Bez względu na klasyfikację, u podłoża wszystkich przywołanych plateonimów legły toponimy istniejące współcześnie.

${ }^{1}$ Były to tereny odebrane Niemcom i przyznane Polsce jako swego rodzaju rekompensata za utracone na rzecz ZSRR Kresy Wschodnie na mocy postanowień konferencji poczdamskiej (lipiecsierpień 1945) obejmujące w szczególności Pomorze Zachodnie, Ziemię Lubuską, Dolny Śląsk, Opolszczyznę, Warmię, Mazury. 
Zdarza się jednak, że motywujący toponim współcześnie nie funkcjonuje². Można wyróżnić kilka wariantów tej sytuacji:

1. Nazwa motywująca jest tworem sztucznym, rekonstruowanym. Za przykład mogą posłużyć nazwy ulic w Poznaniu: Chotomińska, Wieprawska, Ługańska, Kłońska, Dziewińska czy Łuczkowska - wszystkie one (oraz inne, tu niewspomniane, por. Walkowiak, 2019) nawiązują do słowiańskich rekonstruowanych odpowiedników nazw miejscowych i wodnych w Niemczech, np. Dziewin to słowiański rekonstruowany odpowiednik nazwy Magdeburg. Z racji swej genezy nazwy te są nieprzejrzyste etymologicznie nie tylko w planie współczesnym, ale były takimi zapewne już w chwili nominacji, czyli w pierwszych latach powojennych.

2. Nazwa motywująca niegdyś funkcjonowała jako urzędowa, lecz znikła z oficjalnego obiegu (Czechosłowacja, Syjam, Birma, Jugosławia, Stalinogród, Leningrad). Często za zmianą toponimu podąża zmiana plateonimu (np. po śmierci Stalina ulica Stalinogrodzka wróciła do nazwy Katowicka), choć do dziś jest w Polsce ul. Birmańska, Syjamska oraz kilka Czechosłowackich i Jugosłowiańskich. Na uwagę zasługują ulice o nazwie Królewiecka w Elblągu, Braniewie, Mrągowie, Tolkmicku, Gołdapi i Pieniężnie: wszystkie są kierunkowe i wiodą do dawnego Królewca, obecnego Kaliningradu. Ich motywacja jest dla współczesnego odbiorcy stosunkowo czytelna, gdyż znajomość nazw je motywujących jest elementem wiedzy ogólnej.

3. Nazwa motywująca to nazwa przejściowa — takie właśnie plateonimy zostaną przedstawione $\mathrm{w}$ niniejszym artykule.

\section{NAZWY PRZEJŚCIOWE (TZW. PRZEDKOMISYJNE) I PROBLEMY Z IDENTYFIKACJĄ MOTYWOWANYCH NIMI PLATEONIMÓW}

Nazwy ulic typu Zemska (Wrocław) czy Broniszewska (Gryfice) łączy to, że można je interpretować jako nawiązujące (w sposób realnoznaczeniowy — często jako nazwy kierunkowe bądź w sposób konwencjonalny — jako nazwy pamiątkowe) do nazw przejściowych (przedkomisyjnych), obecnie nieużywanych, funkcjonujących na tzw. Ziemiach Odzyskanych bezpośrednio po wojnie. Mimo że nazwy te czasami czerpano z opracowań np. Stanisława Kozierowskiego ${ }^{3}$ czy — na Śląsku — Antoniego Wrzoska ${ }^{4}$, najczęściej były one wynikiem

\footnotetext{
${ }^{2}$ Pomijamy nazewnictwo miejskie motywowane przez polskie egzonimy, jak ul. Kowieńska (oryginalny toponim: Kaunas).

${ }^{3}$ Por. Rymar (2010, s. 181-182).

${ }^{4}$ Por. np. hasło Sobczyce w t. 15 słownika „Nazwy miejscowe Polski” (Czopek-Kopciuch i Bijak (red.), 2018, s. 6).
} 
[...] żywiołowej, często wielotorowej, a dyktowanej koniecznością, działalności nazwotwórczej władz lokalnych różnych szczebli, dyrekcji kolejowych, pocztowych, zarządów lasów oraz samej ludności zarówno miejscowej, jak i przybywającej z różnych stron kraju, zwłaszcza z ziem utraconych na rzecz ZSRR. Zdarzało się więc często, że do czasu nadania oficjalnej urzędowej nazwy przez Komisję Ustalania Nazw Miejscowych jedna miejscowość miała nawet kilka nazw używanych przez lokalną społeczność, urzędy administracji państwowej, Kościół oraz różnego rodzaju instytucje. Te nazwy tymczasowe zwykło się określać terminem „nazwy przejściowe” lub ,przedkomisyjne”, gdyż były one w obiegu do czasu ich weryfikacji przez Komisję Ustalania Nazw Miejscowych (Choroś, Jarczak, 1998, s. 53).

Od zakończenia II wojny światowej problematyka zmian nazw na tzw. Ziemiach Odzyskanych zyskała już bogatą literaturę — dotyczy to zarówno prac tworzonych niejako na bieżąco, równolegle z pracami KUNM (por. np. Nitsch, 1945), jak i późniejszych opracowań analityczno-krytycznych, pisanych już z nieco innej perspektywy (np. Jarczak, Choroś, 1998; Swoboda, 2015; WagińskaMarzec, 2017 i wiele innych). W części tych prac omawiane bądź wspomniane są też nazwy przejściowe:

Nazwy te były z reguły odmienne od późniejszych, oficjalnie ustalonych i uchwalonych komisyjnie, na przykład w wypadku niemieckiej miejscowości Bad Altheide nazwa administracyjna to Puszczyków, kolejowa - Wrześniów, a ustawowa - Polanica-Zdrój. Za przykład takiego chaosu nazewniczego może posłużyć miejscowość w powiecie sulęcińskim, której niemiecka nazwa to Sternberg, kolejowa — Gwiazdowiec, administracyjna — Torun Lubuski, a ustawowa - Torzym. [...] Jednocześnie często funkcjonowały liczne nazwy lokalne, nadawane przez miejscową ludność, będące z reguły dosłownym tłumaczeniem nazw niemieckich. [...] Warto dodać, iż wszelkie tego typu nazwy nie zanikły od razu po wprowadzeniu oficjalnego nazewnictwa i niejednokrotnie funkcjonowały jeszcze przez długi czas, zwłaszcza w świadomości lokalnych mieszkańców (Utracki, 2013, s. 54-55).

Od przyjętej perspektywy i od stopnia akceptacji działań KUNM (zwykle w tekstach dawniejszych był on wyższy, ale też opracowania współczesne nie zawsze cechuje krytyczny dystans) zależy pogląd na mechanizmy kreacji nazw przedkomisyjnych. Mogą one być postrzegane jako ,przypadkowo dobrane”, jako „dowolnie poskładane litery bez jakiegokolwiek sensu” (Sochacka, 2017, s. 344), ale spotyka się też próby zrozumienia szczególnej sytuacji psychologicznej przesiedleńców i interpretacji czy klasyfikacji tworzonych przez nich nazw:

Nie do rzadkości należały sytuacje, kiedy osadnicy nadawali miejscowościom nazwy znane im ze stron rodzinnych, by utrwalić w świadomości następnych pokoleń pamięć o ziemiach utraconych. Czyniono tak, mimo że przedstawiciele nauki przestrzegali przed „,mechanicznym przenoszeniem" nazw geograficznych z dawnych Kresów Wschodnich. Zdarzało się jednak, że lokalne władze szanowały i przychylały się do takich wyborów, używając i firmując przez to nazwy przeniesione. Tak było np. ze „Świtezią”, nowym określeniem nadanym przez repatriantów Tolkmicku (Tomkiewicz, 2004, s. 540). 
Główną tendencją było dosłowne lub przybliżone tłumaczenie nazwy niemieckiej. Pojawiły się także swoiste chrzty o zabarwieniu patriotycznym lub propagandowym (Wolność, Polonia, Polska, Żymirów, Bierutowo). Dość typowe było nadawanie miejscowościom nazw odimiennych, stąd w propozycjach odnajdziemy, m.in. Michałówkę, Romanówkę, Romanowo, Stefanówkę, Zosinek, Bolesławowo, Janów, Konradów [...], Adamowo, Janowo, Józefowo i Kazimierzowo (Wełniak, 2008, s. 179).

Wśród spontanicznie tworzonych określeń nie brakowało odnoszących się do niedawnej walki z III Rzeszą, np. w zachodniopomorskim były to Akowo (dziś Warzynice) i Narwik (dziś Czarna Łąka). Nie mniej popularne były nazwy włączające Ziemie Zachodnie w symbolikę ojczyzny ideologicznej: Chrobryń (dziś Lisie Pole), Piastów (dziś Psary) (Targański, 2016, s. 129).

Analiza wspomnianych wyżej nazw Zemska, Włodarzewska, Broniszewska ujawnia problemy wiążące się z ich poprawną interpretacją. Pierwszy z plateonimów motywowany jest nazwą Zemsz — przejściową (1945-1947) nazwą miasta Lubsko i choć młodszym mieszkańcom nazwa ta może nie być znana, związek motywacyjny nie nastręcza wątpliwości, a brzmienie jednoznacznie wskazuje na odtoponimiczną genezę.

Z inną sytuacją mamy do czynienia w wypadku ul. Broniszewskiej; według urzędowego wykazu mamy w Polsce zarówno wieś Broniszew, jak i pięć wsi oraz jedną kolonię o nazwie Broniszewo. O prawidłowym rozpoznaniu motywacji analizowanego plateonimu przesądza jednak to, że jest to nazwa kierunkowa - ulica prowadzi do pobliskiej wsi Brojce, do której odnosiła się powojenna nazwa przejściowa Broniszewo. Być może jest to zatem nazwa lokalnie przejrzysta motywacyjnie, przynajmniej dla starszych mieszkańców.

W niektórych wypadkach nazwa przejściowa stanowiła jednocześnie potwierdzony źródłowo odpowiednik polski — była więc nazwą używaną w obiegu nieoficjalnym przez miejscową ludność i/lub jako egzonim już wcześniej, jak np. Nibork, Szafeld, Wotyń, Ządźbork. Istniały również, a czasem istnieją do dziś nazwy ulic motywowane dawnymi, obecnie nieużywanymi polskimi egzonimami historycznymi, niestanowiącymi wszakże nazw przedkomisyjnych. Przykładem może być (zniesiona w 2016 roku) nazwa ulicy Libawska w Warszawie — od spolszczenia Libawa (łot. Liepāja, niem. Libau) obecnie Lipawa (Urbańczyk, 1976, s. 314-315), lub Prośnicka w Poznaniu (Prośnica — historyczna polska nazwa rzeki Parsęty $\left.{ }^{5}\right)$.

Długie życie niektórych nazw przejściowych dobrze ilustruje historia toponimu Łuczany, stanowiącego powojenną nazwę przejściową miasta Lötzen (po mazursku Lec). Była ona używana w obiegu oficjalnym do 1946 roku, gdy zmieniono ją

5 Jak podaje „Elektroniczny słownik hydronimów Polski” (https://eshp.ijp.pan.pl/search/ results/241544), była ona poświadczona w drugiej połowie XIX wieku, między innymi w „Słowniku geograficznym Królestwa Polskiego i innych krajów słowiańskich”. 
na Giżycko, na cześć zasłużonego dla polskości mazurskiego działacza Gustawa Gizewiusza, wywodzącego się z rodu Giżyckich. Przeciw tej zmianie protestowali mieszkańcy miasta, wysyłając bezskutecznie pisma do władz, w tym do prezydenta Bieruta. Jak to ujął przewodniczący KUNM prof. Stanisław Srokowski, "[...] zostawałaby chyba jeszcze apelacja do ONZ w Nowym Jorku" (Białuński, 1998, s. 85; Wagińska-Marzec, 2000, s. 316-324). Nazwa Euczany przetrwała w świadomości mieszkańców miasta ${ }^{6}$. Kanał Giżycki nieformalnie nazywano Łuczańskim, w mieście działały też Klub Sportowy „Luczanin” (Wagińska-Marzec, 2000, s. 324), restauracja Łuczanka oraz Wytwórnia Wyrobów Cukierniczych „Łuczanka”. Ponadto do dziś w bazie TERYT ${ }^{7}$ widnieje nazwa pobliskiej osady Knieja Łuczańska (gmina Kruklanki). Stosunkowo niedawno grupa giżyckich radnych wystąpiła z propozycją usankcjonowania stanu faktycznego poprzez zmianę nazwy kanału z Giżyckiego na Łuczański, co poparli mieszkańcy miasta w konsultacjach, i od 2018 roku zmiana weszła w życie ${ }^{8}$. Nazwa Łuczańska w Węgorzewie ma charakter kierunkowy (ulica prowadzi do Giżycka), w samym zaś Giżycku stanowi relikt czasów powojennych.

Innym przykładem jest nazwa przejściowa Korszyń (obecnie Korsze). W czasach PRL w Korszach działała spółdzielnia Korszynianka9 , a do dziś przez miasto płynie struga o tej samej nazwie. Ponadto lokalnie w potocznym użyciu występuje przymiotnik korszyński (obok zalecanej przez słowniki formy korszeński $)^{10}$. Utrzymywaniu się takich nazw w świadomości społecznej sprzyja wzrost zainteresowania historią lokalną. W Mrągowie realizowany jest program społeczny „Ządźborskie pola pamięci”"1 (Ządźbork — przejściowa i historyczna nazwa Mrągowa). Nazwa jednego z ośrodków wypoczynkowych w Pobierowie to Białobórz — od równobrzmiącej nazwy przejściowej osady w pow. kamieńskim ${ }^{12}$.

${ }^{6}$ Por. np. https://horacy67.blogspot.com/p/wiersze-babci-ireny.html?m=1 (dostęp: 8.07.2021).

7 TERYT (Krajowy Rejestr Urzędowy Podziału Terytorialnego Kraju) jest urzędowym rejestrem podziału terytorialnego Polski, a jego wyszukiwarka jest dostępna pod adresem: https://eteryt.stat. gov.pl/eTeryt/rejestr_teryt/udostepnianie_danych/baza_teryt/uzytkownicy_indywidualni/wyszukiwanie/wyszukiwanie.aspx?contrast=default (dostęp: 7.09.2021).

${ }^{8}$ Rozporządzenie Ministra Spraw Wewnętrznych i Administracji z dnia 14 grudnia 2017 r. sprawie ustalenia, zmiany i zniesienia urzędowych nazw niektórych miejscowości oraz obiektów fizjograficznych (Dz.U. poz. 2401); https://radioolsztyn.pl/od-stycznia-kanal-gizycki-zmieni-nazwe-na-luczanski-tak-byla-wola-mieszkancow/01365187 (dostęp: 8.07.2021), http://gac.gizycko.pl/ items/show/9883 (dostęp: 8.07.2021).

${ }^{9}$ https://www.kochamywarmie.pl/2015/02/przystanek-mazury-stary-parowoz-i-korsze.html (dostęp: 8.07.2021).

${ }_{10} \mathrm{https} / / /$ jezykotw.webd.pl/wiki/U\%C5\%BCytkownik:Dynozaur/Nazwy_miejscowe_w_ Prusiech\#Powiat_z.C4.85dzborski_.28mr.C4.85gowski.29 (dostęp: 8.07.2021).

${ }^{11} \mathrm{https} / / /$ www.it.mragowo.pl/zadzborskie-pola-pamieci,1,4016,pl.html (dostęp: 8.07.2021).

${ }^{12}$ Niem. Baldebuß, nazwa ustalona Białobudz (Białecki, 2002, s. 25), ob. nieformalnie Białobudż. 


\section{PLATEONIMY OD NAZW PRZEJŚCIOWYCH UŻYWANE OBECNIE}

Powojenne nazwy przejściowe, które stały się podstawą omawianych w artykule plateonimów, wyekscerpowano z prac historyków i regionalistów (Białecki, 2002 dla Pomorza Zachodniego; Choroś i Jarczak, 1998 dla Opolszczyzny; Siciński, 1991, 1992 dla Dolnego Śląska oraz południowej części Ziemi Lubuskiej; Wagińska-Marzec, 2000 dla Warmii i Mazur; Wełniak, 2008 dla okolic Elbląga; Zysnarski, 2007 dla Gorzowa Wlkp.), a także z innych źródeł, takich jak prasa regionalna oraz strony internetowe gmin i poszczególnych miejscowości. Istnienie pochodzących od nich plateonimów weryfikowano następnie w bazie TERYT, a ich lokalizację — na mapach Google, ponieważ kierunkowy charakter ulicy bądź jej przynależność do gniazda nazewniczego motywowanego nazwami miejscowości na Ziemiach Odzyskanych stanowiły dodatkowy argument przemawiający za włączeniem nazwy do analizowanego zbioru. Wyniki ekscerpcji przedstawiono w tabeli 1. Dla każdej znalezionej nazwy ulicy podano miejscowość, w której się ona znajduje, a także motywujący ją toponim wraz z odpowiednikiem niemieckim i formą ostatecznie ustaloną przez KUNM. O nazwach przejściowych stanowiących motywację dla omawianych w artykule plateonimów można mówić oczywiście wyłącznie w kontekście Ziem Odzyskanych, jednak motywowane nimi plateonimy występują — jak się okazuje — również poza tym obszarem, o czym szerzej w podsumowaniu.

Komentarza wymaga obecność w tabeli ul. Wotyńskiej. W większości wypadków (np. w Poznaniu, gdzie z Wołyńską sąsiadują ulice Pomorska, Mazowiecka, Śląska, a całe gniazdo nazewnicze powstało jeszcze przed wojną i upamiętniało krainy geograficzno-historyczne Polski w jej ówczesnych granicach) podstawą nazwy jest Wotyń - kraina historyczna w granicach współczesnej Ukrainy. We Wrocławiu nazwy ulic sąsiadujących z Wołyńska (jak Uznamska, Helska, Dziwnowska) każą jednak podejrzewać, że nazwa motywowana jest słowiańską ${ }^{13}$ nazwą wyspy lub miasta Wolin (niem. Wollin). Podobna może być geneza plateonimu w Szczecinie (Białecki, 2002, s. 240, 241 ${ }^{14}$ ).

Niekiedy nazwy ulic upamiętniają dawną (przedkomisyjną) nazwę właśnie tej miejscowości, w której ulica się znajduje, podobnie do wspomnianej ul. Łuczańskiej w Giżycku. Za przykład mogą posłużyć ul. Solicka w SzczawnieZdroju (nazwa przejściowa Solice-Zdrój) (por. Choroś, 2018, s. 423; Urbańczyk, 1947) oraz ul. Nowej Naprawy w Lubrzy (jej nazwa przejściowa brzmiała Nowa Naprawa, co wynika stąd, że powojenni osadnicy pochodzili w znacznej części z Podhala, ze wsi Naprawa koło Rabki ${ }^{15}$ ).

${ }^{13}$ Nazwa Wotyń, która pojawia się między innymi w przedwojennych pracach S. Kozierowskiego, używana była w odniesieniu do Wolina (wyspy i miasta) bezpośrednio po wojnie.

${ }_{14}$ Por. też „Kurier Szczeciński” (7-8.10.1945, nr 1, s. 1).

${ }^{15} \mathrm{https} / / /$ nto.pl/jak-gorale-zalozyli-nowa-naprawe/ar/4665514 (dostęp: 8.07.2021). 
Tabela 1. Plateonimy od nazw przejściowych używane obecnie

\begin{tabular}{|c|c|c|c|c|}
\hline \multicolumn{2}{|c|}{ Plateonim } & \multicolumn{3}{|c|}{ Nazwa motywująca } \\
\hline Nazwa & Lokalizacja & Przejściowa & Niemiecka & Obecna \\
\hline Białkowska & Wrocław & Białka $^{16}$ & Oderbeltsch & Bełcz Wielki \\
\hline Bielawska & $\begin{array}{l}\text { Chojnów (pow. } \\
\text { legnicki, D) }\end{array}$ & Bielawa & Bielau & $\begin{array}{l}\text { Biała, gm. } \\
\text { Chojnów (pow. } \\
\text { legnicki, D) }\end{array}$ \\
\hline Borkowska & Brzozowiec $(\mathrm{F})$ & Borkow & Borkow & Borek \\
\hline Borkowska & Ciecierzyce (F) & Borkow & Borkow & Borek \\
\hline Brodzka $^{17}$ & Wrocław & Bródź & Herrnprotsch & $\begin{array}{l}\text { Pracze } \\
\text { Odrzańskie } \\
\text { (część } \\
\text { Wrocławia) }\end{array}$ \\
\hline Broniszewska & Gryfice $(Z)$ & Broniszewo & Broitz & Brojce \\
\hline Bystrzycka & $\begin{array}{l}\text { Dziećmorowice } \\
\text { (D) }\end{array}$ & Bystrzyck & Wüstegiersdorf & Głuszyca (D) \\
\hline Chojnowska & $\begin{array}{l}\text { Jedlina-Zdrój } \\
\text { (D) }\end{array}$ & Chojna & Kynau & $\begin{array}{l}\text { Zagórze Śląskie } \\
\text { (D) }\end{array}$ \\
\hline Cylichowska & Warszawa & Cylichów & Züllichau & Sulechów \\
\hline Czernicka & Wrocław & Czernice & $\begin{array}{l}\text { Tscharnitz } \\
\text { (Schwartzmühle) }\end{array}$ & Czarnyż (D) \\
\hline $\begin{array}{l}\text { Czerwona } \\
\text { Dolina }\end{array}$ & $\begin{array}{l}\text { Sosnówka (pow. } \\
\text { karkonoski, D) }\end{array}$ & $\begin{array}{l}\text { Czerwona } \\
\text { Dolina }\end{array}$ & Rothengrund & Czerwoniak \\
\hline $\begin{array}{l}\text { Czerwony } \\
\text { Dworek }\end{array}$ & $\begin{array}{l}\text { Mysłakowice } \\
\text { (D) }\end{array}$ & $\begin{array}{l}\text { Czerwony } \\
\text { Dworek }\end{array}$ & Rothervorwerk & $\begin{array}{l}\text { Czestków (ob. } \\
\text { przysiółek wsi } \\
\text { Mysłakowice) }\end{array}$ \\
\hline Gierdawska & Warszawa & Gierdawy ${ }^{18}$ & Gerdauen & $\begin{array}{l}\text { Żelezno- } \\
\text { dorożnyj } \\
\text { (Obwód } \\
\text { Kaliningradzki) }\end{array}$ \\
\hline Goleszańska & $\begin{array}{l}\text { Chojnów (pow. } \\
\text { legnicki, D) }\end{array}$ & Goleszany & Göllschau & Goliszów (D) \\
\hline Gołnowska $^{19}$ & Wrocław & Gołonóg & Gollnow & Goleniów \\
\hline
\end{tabular}

16 Jest to prawdopodobna motywacja nazwy z uwagi na sąsiedztwo ulic o nazwach motywowanych nazwami innych wsi na Dolnym Śląsku (np. Dłużycka : Dłużyce, Wilkszyńska : Wilkszyn, Grębocicka : Grębocice).

${ }^{17}$ Niem. Herrnprotscher Str. (od 1931 r.).

${ }^{18}$ Krótko po wojnie w granicach Polski jako stolica powiatu gierdawskiego, jesienią $1945 \mathrm{r}$. przejęta przez ZSRR.

19 Nazwa nawiązuje bezpośrednio do spolszczonej fonetycznie nazwy niemieckiej. Co ciekawe, w Szczecinie zachowała się nazwa Nabrzeże „Golnów” (https://www.prawo.pl/ akty/m-p-1958-96-522,16812444.html; dostęp: 8.07.2021, http://port.szczecin.pl/files/port/ 


\begin{tabular}{|c|c|c|c|c|}
\hline Górska & Jeziorany (N) & Górsko ${ }^{20}$ & $\begin{array}{l}\text { Landsberg } \\
\text { (Ostpreußen) }\end{array}$ & $\begin{array}{l}\text { Górowo } \\
\text { Iławeckie (N) }\end{array}$ \\
\hline Gronowska & Strzegom (D) & (nie ustalono) & $\begin{array}{l}\text { Grunau bei } \\
\text { Striegau }\end{array}$ & Skarżyce $^{21}$ \\
\hline Gryfiogórska & Lubomierz (D) & Gryfia Góra & Greiffenberg & Gryfów Śląski \\
\hline Gumbińska & Gołdap (N) & (nie ustalono) & Gumbinnen & $\begin{array}{l}\text { Gusiew (Obwód } \\
\text { Kaliningradzki) }\end{array}$ \\
\hline Hermanowska & Wrocław & Hermanowo $^{22}$ & Herrmannsdorf & Jerzmanowo \\
\hline Jagielnicka & $\begin{array}{l}\text { Ścinawa Mała } \\
(\mathrm{O})\end{array}$ & Jagielnica & Jäglitz & Jegielnica \\
\hline Janczarska & $\begin{array}{l}\text { Legnickie Pole } \\
\text { (D) }\end{array}$ & Janczary $^{23}$ & Janis (Janisch) & $\begin{array}{l}\text { Janiszów (ob. } \\
\text { część wsi } \\
\text { Legnickie Pole, } \\
\text { D) }\end{array}$ \\
\hline Jaśkowicka & Wrocław & Jaśkowice ${ }^{24}$ & $\begin{array}{l}\text { Jäschkowitz } \\
\text { (Langefeld) }\end{array}$ & $\begin{array}{l}\text { Jeszkowice } \\
\text { (wieś w pow. } \\
\text { wrocławskim) }\end{array}$ \\
\hline Kaczanowska & Przemków (D) & Kaczanów & Kotzenau & Chocianów (D) \\
\hline Knignicka & Wrocław & $\begin{array}{l}\text { Knignice }^{25} \text {, } \\
\text { Książenice }^{26}\end{array}$ & $\begin{array}{l}\text { (Polnisch) } \\
\text { Kniegnitz, } \\
\text { Elfhofen }\end{array}$ & Księginice \\
\hline $\begin{array}{l}\text { Kobylo- } \\
\text { górska }^{27}\end{array}$ & $\begin{array}{l}\text { Gorzów Wlkp. } \\
\text { (F) }\end{array}$ & $\begin{array}{l}\text { Kobyla Góra/ } \\
\text { Kobylagóra }\end{array}$ & $\begin{array}{l}\text { Landsberg an der } \\
\text { Warthe }\end{array}$ & Gorzów Wlkp. \\
\hline
\end{tabular}

Instrukcja_ruchu_i_eksploatacji_sieci_dystrybucyjnej.pdf, https://zdrowiedlawszystkich.pl/index.php/ komorka/179553/przychodnia-miedzyzakladowa-zarzadu-morskiego-portu-szczecin-swinoujscie-s-a-nabrzeze-golnow, dostęp: 8.07.2021), choć nie figuruje ona w bazie TERYT.

${ }^{20}$ Por. Wagińska-Marzec (2000, s. 348).

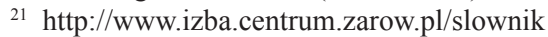

${ }_{22}$ Dawne osiedle w południowo-zachodniej części Wrocławia, https://ossolineum.pl/index. php/75-lat-powojennego-wroclawia-zaklad-narodowy-im-ossolinskich/plan-wroclawia-z-1946-r/ (dostęp: 8.07.2021), http://fotopolska.eu/378658,foto.html? $\mathrm{a}=969 \& \mathrm{~b}=2098 \& \mathrm{c}=5$ (dostęp: 8.07.2021).

${ }^{23}$ W „Podziale administracyjnym” woj. legnickiego z 1 czerwca 1975 r. Janiszów-Janczary figuruje jako integralna część miejscowości Legnickie Pole.

${ }^{24}$ Pochodzenie nazwy ulicy od toponimu Jaśkowice jest wysoce prawdopodobne - w pobliżu biegną też ul. Dobrzykowicka, Nadolicka, Łaniewska, Jelczańska (żadna nie jest jednak ulicą o nazwie kierunkowej), o nazwach motywowanych nazwami pobliskich wsi Dobrzykowice, Nadolice, Łany, Jelcz (od 1987 r. miasto Jelcz-Laskowice).

${ }^{25}$ Por. Nitsch $(1945$, s. 35).

${ }^{26}$ Por. Siciński (1991, s. 153).

${ }^{27}$ Nazwa niem. Kuhburgerstrasse (Zysnarski, 2007, s. 50) nawiązuje do bydła, nie do koni. 


\begin{tabular}{|c|c|c|c|c|}
\hline Kolbaczewska & Warszawa & Kolbacz $^{28}$ & Kolbatz & Kołbacz \\
\hline Koniawska & $\begin{array}{l}\text { Gorzów Wlkp. } \\
\text { (F) }\end{array}$ & Koniawa $^{29}$ & Rosswiese & Zieleniec \\
\hline Korszyńska & Sępopol (N) & Korszyn & Korschen & Korsze $(\mathrm{N})$ \\
\hline Kożuchowska & Wrocław & Kożuchów ${ }^{30}$ & Bischofswalde & $\begin{array}{l}\text { Biskupin }^{31} \\
\text { (część } \\
\text { Wrocławia) }\end{array}$ \\
\hline Królewiecka & $\begin{array}{l}\text { Krzywin } \\
\text { Gryfiński (Z) }\end{array}$ & $\begin{array}{l}\text { Królewiec, } \\
\text { Królewiec nad } \\
\text { Odrą }\end{array}$ & $\begin{array}{l}\text { Königsberg in } \\
\text { der Neumark }\end{array}$ & Chojna \\
\hline Królewiecka & Myślibórz (Z) & $\begin{array}{l}\text { Królewiec, } \\
\text { Królewiec nad } \\
\text { Odrą }\end{array}$ & $\begin{array}{l}\text { Königsberg in } \\
\text { der Neumark }\end{array}$ & Chojna \\
\hline Królewiecka & $\begin{array}{l}\text { Drawsko Pom. } \\
\text { (Z) }\end{array}$ & $\begin{array}{l}\text { Królewiec, } \\
\text { Królewiec nad } \\
\text { Odrą }\end{array}$ & $\begin{array}{l}\text { Königsberg in } \\
\text { der Neumark }\end{array}$ & Chojna \\
\hline Litomska & Wrocław & Litom & Leuthen & Lutynia $^{32}$ \\
\hline Łasicka & Bolesławiec (D) & Losice & Looswitz & $\begin{array}{l}\text { Łaziska (pow. } \\
\text { bolesławiecki) }\end{array}$ \\
\hline Łozińska & Pruszowice (D) & Lozina $^{33}$ & Lossen & $\operatorname{Losina}^{34}(\mathrm{D})$ \\
\hline Łuczańska & Giżycko (N) & Łuczany & Lötzen & Giżycko \\
\hline Łuczańska & Węgorzewo (N) & Łuczany & Lötzen & Giżycko \\
\hline Małoszyńska & Poznań & $\begin{array}{l}\text { Małoszyn, } \\
\text { Maleszyce }\end{array}$ & Maltsch & Malczyce \\
\hline
\end{tabular}

${ }^{28}$ T. Białecki (2002, s. 101) podaje Kolbacz jako nazwę przejściową wsi Kołbacz w woj. zachodniopomorskim (powiat gryficki, gmina Stare Czarnowo). Ulica w Warszawie do 2012 r. nosiła nazwę Kolbaczowska.

${ }^{29}$ „Das Roß = koń, rumak, die Wiese = łąka, czyli «końska łąka», łąka tej nazwy wspomniana już w 1372 r. Stąd Koniawa, jako próba spolszczenia tej nazwy” (Zysnarski, 2007, s. 60)

${ }^{30}$ Jak podaje Z. Antkowiak, ,,[w] średniowieczu istniała na terenie obecnego Biskupina osada o nazwie Koczotów. [...] Nieudolne średniowieczne zapisy próbowano też zrekonstruować jako Kożuchów, co wszelako jest nieuzasadnione" (Antkowiak, 1973, s. 24).

31 „Nazwę Biskupin zaproponował po wyzwoleniu prof. Witold Taszycki. Utrzymała się ona, mimo że uprzednio zwracano uwagę, iż prawidłowym mianem [...] byłby Koczotów (czy też Kożuchów, jak wówczas błędnie mniemano). Kożuchów pojawia się m.in. na planach miasta z r. 1947. Ostatecznie jednak w r. 1948 nazwa Biskupin została zatwierdzona jako obowiązująca urzędowo" (Antkowiak, 1973, s. 27).

${ }^{32}$ Przedwojenna niemiecka nazwa ul. Litomskiej to Leuthenstrasse (od Leuthen - Lutynia) na cześć zwycięstwa wojsk pruskich nad austriackimi pod Lutynią (1757 r.). https://polska-org. pl/586600,Wroclaw,ul_Litomska.html (dostęp: 8.07.2021).

${ }^{33}$ Por. Siciński (1991, s. 155).

${ }^{34}$ Do 1958 r., ob. Łozina. 


\begin{tabular}{|c|c|c|c|c|}
\hline Małoszyńska & Wrocław & $\begin{array}{l}\text { Małoszyn, } \\
\text { Maleszyce }\end{array}$ & Maltsch & Malczyce $^{35}$ \\
\hline Niborska & Elbląg & Nibork & Neidenburg & Nidzica (N) \\
\hline Niborska & Olsztyn & Nibork & Neidenburg & Nidzica $(\mathrm{N})$ \\
\hline Niborska & Wrocław & Nibork & Neidenburg & Nidzica $(\mathrm{N})$ \\
\hline $\begin{array}{l}\text { Gościniec } \\
\text { Niborski }\end{array}$ & Bartąg (N) & Nibork & Neidenburg & Nidzica $(\mathrm{N})$ \\
\hline Niemkińska & Wrocław & Niemkini & Nimkau & Miękinia \\
\hline Niepierzyńska & Wrocław & Niepierzyn & Nippern & $\begin{array}{l}\text { Mrozów (D, } \\
\text { pow. średzki) }\end{array}$ \\
\hline Nowy Dom & Wałbrzych (D) & (nie ustalono) & Burg Neuhaus & $\begin{array}{l}\text { Zamek Nowy } \\
\text { Dwór }^{36}\end{array}$ \\
\hline Nowy Dwór & $\begin{array}{l}\text { Gorzów Wlkp. } \\
\text { (F) }\end{array}$ & Nowy Dwór & $\begin{array}{l}\text { Neusoest/Neu } \\
\text { Soest }\end{array}$ & Zielnica $(\mathrm{F})$ \\
\hline Odyniec & $\begin{array}{l}\text { Szczepanów } \\
\text { (pow. średzki, D) }\end{array}$ & Odyniec & $\begin{array}{l}\text { Vorwerk } \\
\text { Schweinberg }\end{array}$ & Świnka $^{37}$ \\
\hline Opolowska & Bogatynia (D) & Opolówka & Bad Oppelsdorf & Opolno-Zdrój \\
\hline Pankowicka & $\begin{array}{l}\text { Wierzbna pow. } \\
\text { świdnicki (D) }\end{array}$ & Pankowice & Penkendorf & Panków (D) \\
\hline Pawicka $^{38}$ & Legnica (D) & Pawice & Pfaffendorf & $\begin{array}{l}\text { Piątnica } \\
(\text { ob. część } \\
\left.\text { Legnicy }^{39}\right)\end{array}$ \\
\hline Perkunowska & Giżycko (N) & Perkunowo ${ }^{40}$ & Pierkunowen & Pierkunowo (N) \\
\hline Pięknej Wody & Księginice (D) & Piękna Woda & $\begin{array}{l}\text { Wasserjentsch } \\
\text { (Schönwasser) }\end{array}$ & $\begin{array}{l}\text { Komorowice } \\
\text { (gm. Żórawina, D) }\end{array}$ \\
\hline Przybytowska & Tolkmicko (N) & Przybytów & Dünhofen & Przybyłowo \\
\hline $\begin{array}{l}\text { Puszczy- } \\
\text { kowska }^{41}\end{array}$ & Wrocław & Puszczyków & Bad Altheide & Polanica Zdrój \\
\hline
\end{tabular}

${ }^{35}$ Por. Nitsch (1945, s. 40). Nazwę „Małoszyn” nosiła też po wojnie cukrownia w Malczycach, por. https://mukmalczyce.pl/historia/historia-malczyce/ (dostęp: 8.07.2021).

${ }^{36} \mathrm{https}: / /$ www.zamkipolskie.com/ndwor/ndwor.html (dostęp: 8.07.2021).

${ }^{37}$ Tak podaje B. Siciński (1991, s. 154), w bazie TERYT brak; por. też https://polska-org. pl/7424173,Szczepanow,Odyniec_przysiolek.html, http://www.mojemiasto.swidnica.pl/?p=14178 (dostęp: 8.07.2021).

${ }^{38}$ Nazwa Pawice do dziś funkcjonuje w kartografii i rejestrach nazewniczych jako niestandaryzowana nazwa części Legnicy (PRNG), w której zlokalizowana jest ul. Pawicka, w pobliżu położony jest również Lasek Pawicki.

${ }^{39}$ Por. http://liegnitz.pl/index.php?OBJ/725 (dostęp: 8.07.2021).

40 Por. https://ugg.pl/cms/22101/pierkunowo (dostęp: 8.07.2021).

${ }^{41}$ „Enklawę budynków jednorodzinnych [we Wrocławiu na osiedlu Gaj] mamy przy ulicach, których nazwy pochodzą od uzdrowisk (Lądecka, Świeradowska, Puszczykowska itd.)" (Antkowiak, 1973, s. 45). 


\begin{tabular}{|c|c|c|c|c|}
\hline Sernicka & Wrocław & Serniki & $\begin{array}{l}\text { Gr. Sürding } \\
\text { (Schönborn) }\end{array}$ & $\begin{array}{l}\text { Żerniki } \\
\text { Wrocławskie } \\
\text { (część } \\
\text { Wrocławia) }\end{array}$ \\
\hline Starodworska & $\begin{array}{l}\text { Mokry Dwór } \\
\text { (D) }\end{array}$ & (nie ustalono) & Althofnass & $\begin{array}{l}\text { Mokry Dwór } \\
\text { (D) }\end{array}$ \\
\hline Starogrodzka ${ }^{42}$ & Gryfice $(Z)$ & Starogród & $\begin{array}{l}\text { Stargard in } \\
\text { Pommern, } \\
\text { Stargard an der } \\
\text { Ihna }\end{array}$ & $\begin{array}{l}\text { Stargard (do } \\
2015 \text { r. Stargard } \\
\text { Szczeciński) }\end{array}$ \\
\hline Starogrodzka & $\begin{array}{l}\text { Drawsko Pom. } \\
\text { (Z) }\end{array}$ & Starogród & $\begin{array}{l}\text { Stargard in } \\
\text { Pommern, } \\
\text { Stargard an der } \\
\text { Ihna }\end{array}$ & $\begin{array}{l}\text { Stargard (do } \\
2015 \text { r. Stargard } \\
\text { Szczeciński) }\end{array}$ \\
\hline Starogrodzka & Pełczyce (Z) & Starogród & $\begin{array}{l}\text { Stargard in } \\
\text { Pommern, } \\
\text { Stargard an der } \\
\text { Ihna }\end{array}$ & $\begin{array}{l}\text { Stargard (do } \\
2015 \text { r. Stargard } \\
\text { Szczeciński) }\end{array}$ \\
\hline Starowiejska & $\begin{array}{l}\text { Smolec (pow. } \\
\text { wrocławski, D) }\end{array}$ & Stara Wieś & Blankenau & Cesarzowice \\
\hline Starynowska & Kołobrzeg (Z) & Starynow & Alt Werder & Korzystno \\
\hline Stobnicka & Poznań & Stobnica & Groß Stepenitz & Stepnica (Z) \\
\hline Strażnicza $^{43}$ & Elbląg & Strażnica & Kraffohlsdorf $^{44}$ & Bielnik \\
\hline Strumykowa & Elbląg & Strumykowo & Dörbeck & $\begin{array}{l}\text { Próchnik (część } \\
\text { Elbląga) }\end{array}$ \\
\hline Strzygłowska & Warszawa & Strzygłów ${ }^{45}$ & Striegau & Strzegom \\
\hline Sukielicka & Wrocław & Sukielice $^{46}$ & $\begin{array}{l}\text { Tschanchelwitz } \\
\text { (Rübenau) }\end{array}$ & Szukalice (D) \\
\hline Sulejowska $^{47}$ & Wrocław & Sulejewo & Sulau & $\begin{array}{l}\text { Sułów (D, pow. } \\
\text { milicki) }\end{array}$ \\
\hline
\end{tabular}

42 Odmienna jest geneza nazw ul. Starogrodzkiej w Benicach i Lutogniewie w pow. krotoszyńskim (obie prowadzą do pobliskiej wsi Starygród) oraz ul. Starogrodzkiej we wsi Brzozowo, pow. chełmski, woj. kujawsko-pomorskie, wiodącej do pobliskiej wsi Starogród.

${ }^{43}$ Przed wojną Wintertrift: https://www.portel.pl/dawny-elblag/od-grochowskiej-do-stawidlowej-historia-elblaskich-ulic-odcinek-98/88840 (dostęp: 8.07.2021).

${ }^{44}$ Wełniak, 2008, s. 193; https://www.elbing-land-familienforschung.de/seite150.html (dostęp: 8.07.2021).

45 Jak podkreśla J. Miodek (https://www.lo.strzegom.pl/2010/news.php?readmore=650; dostęp: 8.07.2021), nazwa Strzygłów jest nieprawidłowa. Strzygłów to też przejściowa nazwa wsi Trzygłów w pow. gryfickim (Białecki, 2002, s. 208).

${ }^{46} \mathrm{https}: / /$ polska-org.pl/506853,Szukalice.html (dostęp: 8.07.2021).

47 Przed wojną Sulauer Str. 


\begin{tabular}{|c|c|c|c|c|}
\hline Sząfałdzka & Unieszewo $(\mathrm{N})$ & $\begin{array}{l}\text { Sząfałd, Sząfałt, } \\
\text { Szomfald, } \\
\text { Szomfalt, } \\
\text { Szomfałt }^{48}\end{array}$ & Schönfelde & Unieszewo $(\mathrm{N})$ \\
\hline Sztynwałdzka & $\begin{array}{l}\text { Biskupiec } \\
(\text { Pomorski) (N) }\end{array}$ & Sztynwałd & Stangenwalde & Słupnica \\
\hline Węgoborska & Wrocław & Węgobork & Angerburg & Węgorzewo $(\mathrm{N})$ \\
\hline Więzowska & Poznań & Więzów ${ }^{49}$ & Wansen & Wiązów (D) \\
\hline Wołyńska & Szczecin & Wołyń & Wollin & Wolin \\
\hline Wołyńska & Wrocław & Wołyń & Wollin & Wolin \\
\hline Woronowicka & Wrocław & Woronowice & Wohnwitz & $\begin{array}{l}\text { Wojnowice (D, } \\
\text { pow. średzki, } \\
\text { gm. Miękinia) }\end{array}$ \\
\hline Wysokogórska & Bolków (D) & Wysoka Góra & $\begin{array}{l}\text { Hochen- } \\
\text { friedeberg }\end{array}$ & Dobromierz (D) \\
\hline Zagórska & Trzebiatów (Z) & Zagórze & $\begin{array}{l}\text { Greiffenberg in } \\
\text { Pommern }\end{array}$ & Gryfice \\
\hline $\begin{array}{l}\text { Zaułek } \\
\text { Rogoziński }\end{array}$ & Wrocław & Rogozin $^{50}$ & Rosenthal & Różanka $^{51}$ \\
\hline Zemska $^{52}$ & Wrocław & Zemsz & Sommerfeld & Lubsko \\
\hline Zgorzelicka & $\begin{array}{l}\text { Tomaszów Maz. } \\
\text { (E) }\end{array}$ & Zgorzelice & Görlitz & Zgorzelec \\
\hline $\begin{array}{l}\text { Zielonego } \\
\mathrm{Dębu}^{53}\end{array}$ & Wrocław & Zielony Dąb $b^{54}$ & Grüneiche & $\begin{array}{l}\text { Dąbie (część } \\
\text { Wrocławia) }\end{array}$ \\
\hline $\begin{array}{l}\text { Zwierzy- } \\
\text { niecka }\end{array}$ & Oława (D) & Zwierzyniec & Thiergarten & $\begin{array}{l}\text { Zwierzętnik } \\
\text { (część Oławy) }\end{array}$ \\
\hline $\begin{array}{l}\text { Zygmun- } \\
\text { towska }\end{array}$ & $\begin{array}{l}\text { Kożuchów/ } \\
\text { Podbrzezie } \\
\text { Dolne (F) } \\
\end{array}$ & $\begin{array}{l}\text { Zygmuntów } \\
\text { (Dolny, Górny) }\end{array}$ & $\begin{array}{l}\text { Nieder } \\
\text { Siegersdorf, } \\
\text { Ober Siegersdorf }\end{array}$ & $\begin{array}{l}\text { Podbrzezie } \\
\text { (Górne, Dolne) }\end{array}$ \\
\hline Żegańska & Warszawa & Żegań & $\begin{array}{l}\text { Sagan, Sagan in } \\
\text { Schlesien, Sagan } \\
\text { am Bober }\end{array}$ & Żagań (F) \\
\hline
\end{tabular}

${ }^{48}$ Por. Lewandowska (2010, s. 46, 52).

49 https://polska-org.pl/540782,Wiazow,Stacja_kolejowa_Wiazow_dawna.html (dostęp: 8.07.2021).

${ }^{50}$ Jak jednak podaje Z. Antkowiak, ,[n]ie znajduje potwierdzenia teza niemieckiego badacza P. Hefftnera, że pierwotnie wieś nosiła polską nazwę Rogozin. W 1945 r. mieszkańcy samorzutnie nazwali osiedle Różanką i tak zostało" (Antkowiak, 1997, s. 367).

${ }^{51}$ Dawna wieś, ob. osiedle w północnej części Wrocławia.

${ }_{52}$ Nazwa ul. Zemskiej we wsi Piekary (P) pochodzi nie od przedkomisyjnej nazwy Lubska, a od pobliskiej wsi Zemsko, do której prowadzi.

${ }^{53}$ Przedwojenna nazwa niem. ulicy brzmiała Zur Grünen Eiche.

${ }^{54}$ Por. Antkowiak (1997, s. 68). 


\section{PLATEONIMY OD NAZW PRZEJŚCIOWYCH OBECNIE NIEUŻYWANE}

Liczba omawianych powyżej plateonimów byłaby bez wątpienia wyższa, gdyby nie powojenne korekty nazw ulic po ustaleniu przez KUNM ostatecznych postaci urzędowych motywujących je toponimów. Jak na przykład podkreśla A. Gąsiorowski, w Poznaniu „,[w]iele nazw odmiejscowych poprawiono w 1966r. Zmieniono wówczas np. ul. Canowską na Sianowską, Derłowską na Darłowską, Człopowską na Człopską, Białyborską na Białoborską, Wałczewską na Wałecką, Czarnecką na Trzcianecką" (Gąsiorowski, 1984, s. 58). Stało się tak zwykle w związku z korektą samej nazwy motywującej. Przykłady nieistniejących już dziś plateonimów przedstawia poniższa tabela.

Tabela 2. Plateonimy pochodzące od nazw przejściowych obecnie nieużywane — przykłady

\begin{tabular}{|c|c|c|c|c|c|}
\hline \multicolumn{2}{|c|}{ Nazwa ulicy } & \multirow{2}{*}{$\begin{array}{l}\text { Lokaliza- } \\
\text { cja }\end{array}$} & \multicolumn{3}{|c|}{ Motywująca nazwa } \\
\hline Dawna & Obecna & & Przejściowa & Niemiecka & Obecna \\
\hline Canowska & Sianowska & Poznań & Canów & Zanow & Sianów $^{55}$ \\
\hline Chudobicka $^{56}$ & Kudowska & Wrocław & Chudoba & Bad Kudowa & Kudowa-Zdrój \\
\hline Ciążyńska & Księska & Wrocław & $\begin{array}{l}\text { Ciążyn } \\
\text { Wielki, Cią- } \\
\text { żyn Mały }\end{array}$ & $\begin{array}{l}\text { Groß Tschansch, } \\
\text { Klein Tschansch }\end{array}$ & $\begin{array}{l}\text { Księże Wiel- } \\
\text { kie, Księże } \\
\text { Małe }\end{array}$ \\
\hline $\begin{array}{l}\text { Cierniogaj- } \\
\text { ska }^{58}\end{array}$ & $\begin{array}{l}\text { Tarnogaj- } \\
\text { ska }\end{array}$ & Wrocław & Cierniogaj $^{59}$ & Dürrgoy & $\begin{array}{l}\text { Tarnogaj } 60 \\
\text { (część Wroc- } \\
\text { ławia) }\end{array}$ \\
\hline Derłowska & Darłowska & Poznań & $\begin{array}{l}\text { Derłowo, } \\
\text { Derłów }\end{array}$ & Rügenwalde & Darłowo $(\mathrm{Z})$ \\
\hline
\end{tabular}

${ }_{55} \mathrm{https}: / /$ www.sianow.pl/pl/content/can\%C3\%B3w-staje-si\%C4\%99-sianowem (dostęp: 8.07.2021)

${ }^{56} \mathrm{https}$ ://fotopolska.eu/222758,foto.html (dostęp: 8.07.2021).

57 Jak zwraca uwagę Z. Antkowiak, ,,[w]prowadzona wkrótce po wyzwoleniu nazwa Ciążyn była rezultatem błędnej rekonstrukcji średniowiecznych zapisów, dokonanej przez zasłużonego skądinąd badacza zagadnień nazewnictwa miejscowego Śląska, ks. Stanisława Kozierowskiego. Zajmujący się tym problemem po wojnie językoznawcy szybko się spostrzegli, iż zaszło nieporozumienie, dzięki czemu prawidłową formę Księże zaczęto lansować już w r. 1947. Niemniej wrocławianie zdążyli się już przyzwyczaić do nie mającego uzasadnienia Ciążyna i określenie to słyszy się tu i ówdzie do dziś" (Antkowiak, 1973, s. 94).

${ }^{58}$ W latach 1945-1972, por. https://polska-org.p1/502639,Zmiany_nazw_wroclawskich_ulic po_roku_1945.html (dostęp: 8.07.2021); https://polska-org.pl/587430,Wroclaw,ul_Tarnogajska. html (dostęp: 8.07.2021).

${ }^{59}$ W latach 1945-1948, https://osiedle.wroc.pl/index.php/tarnogaj-historia/tarnogaj-historia-tarnogaju (dostęp: 8.07.2021).

${ }^{60}$ Nazwa zaproponowana przez językoznawcę W. Taszyckiego (Antkowiak, 1973, s. 224). 


\begin{tabular}{|c|c|c|c|c|c|}
\hline Gądawska & Gądowska & Wrocław & Gądawa & Klein Gandau & $\begin{array}{l}\text { GądówMały } \\
\text { (część Wroc- } \\
\text { ławia) }\end{array}$ \\
\hline Głogczycka & $\begin{array}{l}\text { Kłokoczy- } \\
\text { cka }^{61}\end{array}$ & Wrocław & $\begin{array}{l}\text { Głogczyce, } \\
\text { Głogszyce }^{62}\end{array}$ & Glogschütz & Kłokoczyce \\
\hline Kiełcowska ${ }^{63}$ & $\begin{array}{l}\text { Kiełczow- } \\
\text { ska }\end{array}$ & Wrocław & $\begin{array}{l}\text { Kiełców, } \\
\text { Kielcow }\end{array}$ & $\begin{array}{l}\text { Groß Weigels- } \\
\text { dorf }\end{array}$ & $\begin{array}{l}\text { Kiełczów (D, } \\
\text { pow. wrocław- } \\
\text { ski) }\end{array}$ \\
\hline $\begin{array}{l}\text { Klęczkow- } \\
\text { ska }^{64}\end{array}$ & $\begin{array}{l}\text { Kleczkow- } \\
\text { ska }\end{array}$ & Wrocław & Klęczków & Kletschkau & $\begin{array}{l}\text { Kleczków } \\
\text { (część Wroc- } \\
\text { ławia) }\end{array}$ \\
\hline $\begin{array}{l}\text { Miłaszewi- } \\
\text { cka }^{65}\end{array}$ & Miłoszycka & Wrocław & $\begin{array}{l}\text { Miłaszo- } \\
\text { wice }\end{array}$ & Meleschwitz & Miłoszyce \\
\hline Swojecka ${ }^{66}$ & $\begin{array}{l}\text { Swojczy- } \\
\text { cka }\end{array}$ & Wrocław & Swojec & Schwoitsch & Swojczyce \\
\hline Torzemska $^{67}$ & $\begin{array}{l}\text { (ul. nie ist- } \\
\text { nieje) }\end{array}$ & Poznań & $\begin{array}{l}\text { Torzem, } \\
\text { Toruń Lubu- } \\
\text { ski }\end{array}$ & Sternberg & Torzym \\
\hline
\end{tabular}

\section{PODSUMOWANIE}

Łącznie wyekscerpowano 85 współcześnie używanych urzędowych nazw ulic pochodzących od nazw przejściowych. Ponad połowa z nich (45) znajduje się w woj. dolnośląskim, z czego aż 23 w samym Wrocławiu. W woj.

${ }^{61}$ Od 20 XII 1974, por. https://www.wratislavia.net/breslau_names.pdf (dostęp: 8.07.2021).

${ }^{62} \mathrm{http}: / /$ fotopolska.eu/378658,foto.html? $\mathrm{a}=4713 \& \mathrm{~b}=3200 \& \mathrm{c}=5$ (dostęp: 8.07.2021).

${ }^{63}$ Do marca $1971 \mathrm{r}$.

${ }^{64}$ Jak podaje Z. Antkowiak, ,,[z]niekształconej nazwy Kletschkau nie używano już pod koniec ubiegłego stulecia i tym niewątpliwie należy tłumaczyć, iż działająca po wyzwoleniu komisja, mająca za zadanie ustalić polskie nazwy wrocławskich osiedli, nie wprowadziła ponownie miana dawnej wsi. Mimo to znalazło się ono w powszechnym użyciu tak mieszkańców, jak i w urzędach, na równi z oficjalnie obowiązującymi nazwami osiedli. Nazwę tę co prawda zniekształcono, tak że przez wiele lat mieliśmy ul. Klęczkowską i w rezultacie także Klęczków. Dopiero kampania przeprowadzona przez «Wieczór Wrocławia» na początku 1971 r., a poświęcona wyrugowaniu licznych nieporozumień w nazewnictwie ulic naszego miasta, spowodowała, że tabliczki z błędnym określeniem tejże ulicy wymieniono. Ponadto 26 kwietnia 1971 r. Miejska Pracownia Geodezyjna zawiadomiła [...], iż obowiązującą formą jest ul. Kleczkowska. W ślad za tym zaczęto też mówić poprawnie - Kleczków, które to określenie uwidoczniono po raz pierwszy na urzędowym planie miasta Wrocławia w r. 1972" (1973, s. 79-80).

${ }^{65} \mathrm{http} / / /$ fotopolska.eu/378658,foto.html? $\mathrm{a}=4776 \& \mathrm{~b}=2015 \& \mathrm{c}=5$ (dostęp: 8.07.2021).

${ }^{66} \mathrm{https}: / /$ polska-org.pl/666449,foto.html?idEntity=587337 (dostęp: 8.07.2021).

${ }^{67}$ Nazwa ta widnieje na planach miasta z 1962, 1965 i 1971 r. O jej skreśleniu z ewidencji donosi „Kronika Miasta Poznania” (45, 1977, nr 4). 
warmińsko-mazurskim znaleziono ich 14 (w tym jedną w Olsztynie), w woj. zachodniopomorskim - 10 (w tym jedną w Szczecinie), w lubuskim sześć, w Warszawie pięć, w Poznaniu trzy; po jednej nazwie przypada na woj. opolskie i łódzkie. Jak zatem ustalono, plateonimy te występują nieomal wyłącznie na tzw. Ziemiach Odzyskanych, podobnie jak motywujące je nazwy przejściowe.

Nazwy ulic objęte namysłem badawczym mogą stanowić zarówno nazwy kierunkowe na terenach wiejskich, jak Broniszewska, jak i nazwy ulic w dużych miastach, o charakterze pamiątkowym, bez motywacji realnoznaczeniowej, jak Żegańska czy Zemska. Ich identyfikacja jest ułatwiona, gdy tworzą one spójne gniazdo nazewnicze, co ma miejsce raczej w mieście, np. we Wrocławiu w dzielnicy Fabryczna, gdzie spotykamy ulice Niepierzyńską, Małoszyńską, Woronowicką i Niemkińską. Wrocław jest zarazem przypadkiem szczególnym pod względem zachowanej obecności nazw przedkomisyjnych w codziennym obiegu:

W sumie sporo z tych nazw pędziło swój półoficjalny żywot w ustach okolicznej ludności przez wiele następnych lat, a niektóre są sporadycznie i dzisiaj spotykane (por. np. nazwy dzielnic Wrocławia Ciążyn zamiast Księże, Cierniogaj zamiast Tarnogaj, Swojec zamiast Swojczyce, Patenice zamiast Partynice, Ołtarzyn zamiast Ołtaszyn) (Siciński, 1991, s. 145-146).

Niektóre współczesne plateonimy są enigmatyczne. Niekiedy (np. ul. Trzmielowicka ${ }^{68}$ we Wrocławiu, niem. Heidauerstrasse) można zasadnie podejrzewać ich pochodzenie od zapomnianych nazw przedkomisyjnych. Niejasna jest też geneza nazwy ul. Rajskiej w Giżycku — może od nazwy grodu jaćwieskiego Raj (na półwyspie na Jeziorze Rajgrodzkim). Motywacją nazwy ul. Rzecznej we wsi Przybymierz (pow. zielonogórski) może być zarówno pobliski ciek wodny, jak i wieś Stanów (niem. Rengersdorf, przejściowa nazwa Rzeka). Podobnych trudności nastręcza homonimia. Przykładowo, nazwa ul. Żółwińskiej w Szczecinie może być motywowana nazwą przejściową Żótwino (niem. Stettin-Scholwin, obecnie Skolwin - osiedle, na którym ulica jest zlokalizowana), co wydaje się najbardziej prawdopodobne, choć istnieją też dwie wsie o nazwie Żótwino: w pow. kamieńskim (niem. Wollmirstädt) i choszczeńskim (niem. Hassendorf). Nazwa ulicy Białodrzewnej we Wrocławiu może być niedokładnym spolszczeniem nazwy niemieckiej (Weißdornweg < Weißdorn 'głóg'), ale można też podejrzewać związek z nazwą Białodrzew - nazwą przejściową wsi w pow. głogowskim (niem. Weissholz, pol. nazwa urzędowa Białołęka). Motywacją nazwy ul. Gorlickiej we Wrocławiu może być nazwa miasta Gorlice na Podkarpaciu lub Gorlice - przejściowa nazwa części Wrocławia (niem. Görlitz, pol. Zgorzelisko). Ulica Łagiewnicka we Wrocławiu może upamiętniać albo wieś Łagiewniki (niem.

${ }^{68}$ Być może istnieje związek plateonimu z nazwą przejściową Trzmielów (niem. Thielau, ob. Radomiłów w pow. lubińskim), por. Siciński (1991, s. 153). 
Heidersdorf) w pow. dzierżoniowskim, albo wieś Golina (niem. Heidersdorf) w pow. wołowskim, nazwa przejściowa Łagiewniki (Siciński, 1991, s. 153). Motywacją nazwy ul. Winnickiej w Elblągu może być Winnica (niem. Weklitz, Wöcklitz, Wöklitz), obecnie Weklice (obok biegną ul. Iławska i Fromborska), ale też nazwa niewielkiej dzielnicy Elbląga Winnica (choć nie leży na jej terenie ani do niej nie prowadzi) lub miasta na Ukrainie (choć w pobliżu nie ma gniazda o podobnej motywacji).

Współczesna nieczytelność motywacyjna nazw ulic pochodzących od toponimów przejściowych doprowadziła niekiedy również do wykreowania swoistych dubletów nazewniczych. We Wrocławiu pomiędzy Leśnicą a osiedlem Żar znajdują się ul. Lutyńska, Lubska i Malczycka, a jednocześnie w dzielnicy Szczepin do dziś biegnie ul. Litomska, na osiedlu Nowy Dwór — Zemska, a w obrębie osiedla Leśnica - Małoszyńska. Każda z tych par nazw odnosi się do jednej miejscowości — raz przez nazwę przejściową, raz poprzez nazwę obecną. W Elblągu jest i ul. Królewiecka, i rondo Kaliningrad. Na marginesie wypada zaznaczyć, że z przypadkami takich dubletów można się spotkać również w obu wcześniej wspomnianych typach plateonimów motywowanych toponimami nieistniejącymi (np. ul. Prośnicka w Poznaniu i bulwar Nad Parsętą w Kołobrzegu; ul. Retry i Radogoska w Szczecinie ${ }^{69}$ ).

\section{SKRÓTY}

D - woj. dolnośląskie

E - województwo łódzkie

F - woj. lubuskie

$\mathrm{N}$ - woj. warmińsko-mazurskie

$\mathrm{O}$ - woj. opolskie

$\mathrm{P}$ - woj. wielkopolskie

$\mathrm{Z}$-woj. zachodniopomorskie

\section{LITERATURA}

Antkowiak, Z. (1973). Stare i nowe osiedla Wroctawia [Old and New Districts of Wrocław]. Wrocław: Zakład Narodowy im. Ossolińskich.

Antkowiak, Z. (1997). Wrocław od A do Z [Wrocław from A to Z]. Wrocław: Zakład Narodowy im. Ossolińskich.

${ }^{69}$ Nazwy obu szczecińskich ulic są motywowane nazwą Radogoszcz (Retra) — ośrodka politycznego plemienia Wieletów na Rugii. 
Białecki, T. (red.). (2002). Słownik wspótczesnych nazw geograficznych Pomorza Zachodniego z nazwami przejściowymi z lat 1945-1948 [Dictionary of Contemporary Geographical Names of Western Pomerania, Including Provisional Names of 1945-1948]. Szczecin: Książnica Pomorska.

Białuński, G. (red.). (1998). Z dziejów Leca (Giżycka): wybór szkiców i źródel [The History of Lec (Giżycko): Selected Essays and Sources]. Olsztyn-Giżycko: Stowarzyszenie „Wspólnota Mazurska".

Choroś, M. (2018). Wybór tekstów ilustrujących proces przemian nazewniczych w latach 19451950 na Śląsku [Selection of texts illustrating naming changes in Silesia 1945-1950]. Rocznik Ziem Zachodnich, 2, 418-439.

Choroś, M. i Jarczak, Ł. (1998). Wykaz przejściowych nazw miejscowych na Opolszczyźnie w latach 1945-1948 [List of provisional place names in Opole Silesia 1945-1948]. Onomastica, $43,53-80$.

Czopek-Kopciuch, B. i Bijak, U. (red.). (2018). Nazwy miejscowe Polski. Historia. Pochodzenie. Zmiany [Place Names of Poland. History. Origin. Changes] (t. 15). Kraków: Instytut Języka Polskiego PAN.

Gąsiorowski, A. (1984). Nazwy poznańskich ulic. Przemiany i trwanie. Wieki XIV-XX. Aneksy: „Pomyłkowi” patroni poznańskich ulic. Zmiany w nazewnictwie ulic Poznania w latach 19811983 [Street names of Poznań: Changes and permanence. Annexes: Mistaken namesakes. Changes in street names of Poznań 1981-1983]. Kronika Miasta Poznania, 3/4, 23-64.

Jarczak, Ł. i Choroś, M. (1998). Przejściowe nazwy miejscowe na Śląsku w latach 1945-1948 (na przykładzie Opolszczyzny) [Provisional placenames in Silesia 1945-1948 (the case of Opole Silesia)]. W: E. Jakus-Borkowa i K. Nowik (red.), Najnowsze przemiany nazewnicze [The Most Recent Naming Changes] (s. 165-174). Warszawa: Energeia.

Lewandowska, I. (2010). Oswajanie poniemieckiej przestrzeni nazewniczej na Warmii i Mazurach po II wojnie światowej [Adapting post-German onymic space in Warmia and Masuria after WW2]. W: J. Nowosielska-Sobel, G. Strauchold i W. Kucharski (red.), Nazwa dokumentem przeszłości regionu [Names Document the Past of the Region] (s. 35-64). Wrocław: Oficyna Wydawnicza „Atut”.

Nitsch, K. (1945). Nazwy miejscowe w odzyskanej Polsce zachodniej [Place names in recovered Western Poland]. Język Polski, 25(2), 33-41.

Podziat administracyjny 1 VI 1975. Województwo legnickie [Administrative division as of June 1, 1975: Legnica Voyvodeship]. (1975). Wrocław: Wojewódzki Urząd Statystyczny. https://www. sbc.org.pl/dlibra/publication/180305/

PRNG - Państwowy Rejestr Nazw Geograficznych. Główny Urząd Geodezji i Kartografii [National Register of Geographical Names]. https://www.geoportal.gov.pl/dane/panstwowy-rejestr-nazw-geograficznych

Rozporządzenie Ministra Spraw Wewnętrznych i Administracji z dnia 14 grudnia 2017 r. W sprawie ustalenia, zmiany i zniesienia urzędowych nazw niektórych miejscowości oraz obiektów fizjograficznych [Regulation of the Minister of the Interior and Administration of December 14,2017 on establishing, changing and abolishing official names of certain places and physiographic objects], Dz.U. poz. 2401. https://dziennikustaw.gov.p1/DU/rok/2017/pozycja/2401

Rymar, E. (2010). Metryka i nazwy miejscowości dawnego powiatu gorzowskiego w granicach z lat 1945-1950 [Place names and their history in the former Gorzów County within its 1945-1950 limits]. Nadwarciański Rocznik Historyczno-Archiwalny, 17, 179-251.

Siciński, B. (1991). Pierwsze powojenne polskie nazwy miejscowe na Dolnym Śląsku. Cz. 1 [First post-war Polish place names in Lower Silesia. Part 1]. Śląski Labirynt Krajoznawczy, $3,145-158$.

Siciński, B. (1992). Pierwsze powojenne polskie nazwy miejscowe na Dolnym Śląsku. Cz. 2 [First post-war Polish place names in Lower Silesia. Part 2]. Ślaski Labirynt Krajoznawczy, 4, 109-122. 
Sochacka, S. (2017). Zmiany nazw miejscowych na Śląsku Opolskim po 1945 r. [Placename changes in Opole Silesia after 1945]. Rocznik Ziem Zachodnich, 1, 341-359.

Swoboda, P. (2015). (Nie)autentyczność mikrotoponimów ustalonych po 1945 roku na tzw. Ziemiach Zachodnich [(In)authenticity of microtoponyms determined after 1945 on so-called Western Lands in Poland]. W: A. Gałkowski i R. Gliwa (red.), Mikrotoponimy i makrotoponimy w komunikacji i literaturze [Microtoponyms and Macrotoponyms in Communication and Literature] (s. 41-54). Łódź: Wydawnictwo UŁ.

Targański, T. (2016). Egzorcyzmy nad słownikiem [Exorcising the dictionary]. W: Z Kresów na Kresy. Wielkie przesiedlenie Polaków. Pomocnik historyczny „Polityki” [From Borderlands to Borderlands. Great Resettlement of Poles] (s. 127-131). Warszawa: Polityka.

Tomkiewicz, R. (2004). O działalności Komisji Ustalania Nazw Miejscowych i Obiektów Fizjograficznych na terenie Warmii i Mazur [Activities of the Commission for the Determination of Place Names in Warmia and Masuria]. Komunikaty Mazursko-Warmińskie, 4, 539-547.

Urbańczyk, S. (1947). Walka o Solice i Chojnasty [The battle for place names Solice and Chojnasty]. Język Polski, 27(2), 46-50.

Urbańczyk, S. (1976). Odpowiedzi Redakcji 541 [The Editor replies]. Język Polski, 56(4), 314-315.

Utracki, D. (2013). Polityka onomastyczna władz jako element przywracania polskości na Ziemiach Zachodnich po II wojnie światowej (na przykładzie nazewnictwa powiatu słubickiego) [Official onomastic policy as part of restoring Polish character of Western Lands after WW2 (the case of Słubice County)]. Studia Zachodnie, 15, 49-65.

Wagińska-Marzec, M. (2000). Społeczność lokalna w obronie „swych” nazw na Warmii i Mazurach [Local community in defence of "its" names in Warmia and Masuria]. W: Z. Mazur (red.), Wspólne dziedzictwo? Ze studiów nad stosunkiem do spuścizny kulturowej na Ziemiach Zachodnich i Pótnocnych [Common Heritage? Research into the Attitudes to Cultural Heritage in Western and Northern Borderlands] (s. 309-354). Poznań: Instytut Zachodni.

Wagińska-Marzec, M. (2017). Wokół zmian nazewnictwa ulic na Ziemiach Zachodnich i Północnych po 1945 r. - wybrane aspekty [On the changes of street names in the Western and Northern Territories after 1945 — selected aspects]. Rocznik Ziem Zachodnich, 1, 384-422.

Walkowiak, J. (2019). Słowiańszczyzna Połabska jako zapoznana motywacja niektórych hodonimów w Poznaniu [Polabian Slavs as unacknowledged motivation for some hodonyms in Poznań]. Język Polski, 99(3), 84-97.

Wełniak, A. (2008). Nazewnictwo przejściowe miejscowości na terenie powiatu elbląskiego w latach 1945-1949 [Provisional placenames in Elbląg County 1945-1949]. Rocznik Elblaski, 21, 175-200.

Zysnarski, J. (2007). Od Abdeckerei do Żwirowej, czyli klucz do toponomastyki Gorzowa [The toponymy of Gorzów]. Nadwarciański Rocznik Historyczno-Archiwalny, 14, 31-70.

\section{SUMMARY}

\section{CONTEMPORARY POLISH STREET NAMES MOTIVATED BY TRANSITIONAL TOPONYMS}

The aim of the article is to present and discuss contemporary street names motivated by transitional (pre-commission) names of places in the so-called Recovered Territories (Ziemie Odzyskane) in Poland. The latter names were often created spontaneously directly after the Second World War by the first settlers to the area, typically existed for a short time only, and usually in a few years gave way to the names finally approved by the Commission for the Determination of Place Names (KUNM). However, not all the hodonyms created from such transitional placenames in the first post-war years have been changed to this day. Thus, these hodonyms constitute a non-obvious relic of spontaneous post-war place naming. 
In the search for them, various lists of transitional placenames available in scholarly literature were used, with the existence of hodonyms potentially derived from them subsequently verified in an allPolish streetname database. The results were additionally confirmed by examining the location of the excerpted hodonyms on the map. Specifically, the fact that the name of the street was indicative of its destination, or that it was part of commemorative theme naming, justified its inclusion among hodonyms derived from transitional placenames. In total, 85 street names in official use have been found, with more than half of them in Lower Silesia, mainly in its capital, Wrocław. It was also established that outside the area of the Recovered Territories, the hodonyms under consideration only appear sporadically.

Keywords: Polish street names, hodonyms, transitional place names, Recovered Territories, Commission for the Determination of Place Names 